\title{
Oorsigartikel
}

\section{Dertig jaar (1975-2005) internasionale aksie vir Christelike hoër onderwys: enkele persoonlike indrukke}

B.J. van der Walt

Skool vir Filosofie

Potchefstroomkampus

Noordwes-Universiteit

POTCHEFSTROOM

E-pos: hannah@intekom.co.za

\section{Abstract}

Thirty years (1975-2005) international action for Christian higher education: a few personal reflections

These personal reflections are written in view and commemoration of the fact that thirty years ago (9-13 September 1975) the formerly Potchefstroom University for Christian Higher Education (today the Potchefstroom campus of the North-West University) manifested farsightedness when it planned and received the First International Conference of Reformed Institutions for Christian Higher Education. The aim of this article is to answer the following three questions: Firstly, how did this initiative develop? (a historical review); secondly, what was the harvest of the past thirty years? (a brief evaluation); and thirdly what can be expected from the future? (a very brief preview).

\section{Samevatting}

Dertig jaar (1975-2005) internasionale aksie vir Christelike hoër onderwys: enkele persoonlike indrukke.

Hierdie persoonlike indrukke is geskryf in die lig van die feit dat dit dertig jaar gelede is (9-13 September 1975) dat die destydse Potchefstroomse Universiteit vir Christelike Hoër Onderwys (tans die Potchefstroomkampus van die Noordwes-Universiteit) die Eerste Internasionale Konferensie vir Christelike Hoër 
Onderwys beplan en ontvang het. Die doel van hierdie artikel is om die volgende drie vrae te beantwoord: Eerstens, hoe het die inisiatief verder ontwikkel? ('n vlugtige terugblik); tweedens, wat was die resultate van die afgelope dertig jaar? ('n kort evaluering van die huidige situasie); en derdens, wat kan in die toekoms verwag word ('n kort vooruitskouing).

\section{Inleiding: 'n besondere mylpaal wat tot refleksie noop}

Wanneer 'n mylpaal bereik word is 'n bestekopname belangrik. Hierdie artikel wil so 'n "balansstaat" opmaak van die internasionale aksie vir Christelike hoër onderwys wat in September 1975 deur die destydse Potchefstroomse Universiteit vir Christelike Hoër Onderwys van stapel gestuur. Vandag staan dit bekend as die International Association for the Promotion of Christian Higher Education (IAPCHE).

Drie belangrike vrae moet beantwoord word. Aangesien die geskiedenis van die aksie nog nie op skrif gestel is nie (vgl. Vander Stelt, 1990:11-14; 1996:16-21; Van der Walt, 2002:123-137; Hulst, 2005:204-208 en Van Eeden, 2005:528, 539), word eerstens kortliks gevra hoe die inisiatief verder in hooftrekke verloop het. Tweedens word gevra na 'n kort evaluering van wat die aksie die afgelope dertig jaar bereik het. ${ }^{1}$ Derdens moet in gedagte gehou word dat die konteks waarbinne hierdie aksie ontstaan het na dertig jaar op internasionale vlak sowel as op die Potchefstroomkampus radikaal verander het.

Dit gaan dus basies oor verlede, hede en toekoms. Of in beelde gestel: daar word in die truspieël na agter gekyk, met die mikroskoop die bestaande ondersoek en deur 'n teleskoop geloer na dit wat dalk nog ver in die verskiet lê.

1 Omdat daar feitlik geen gepubliseerde bronne bestaan wat antwoorde hierop kan gee nie, is hierdie bydrae hoofsaaklik op 'n persoonlike argief, notas en herinneringe gebaseer. Dit sluit 'n meer gedeë studie (wat beslis die IAPCHEargief by Dordt College, Sioux Center, lowa in die VSA sal moet raadpleeg) nie uit nie, maar sal dit verwelkom. Gelukkig word in die postmoderne tyd persoonlike, "klein verhale" soos hierdie een ook weer as waardevol beskou (vgl. Klep, Hoetink \& Emons, 2005). Hierdie artikel is die "oog-en-oor-getuie" van iemand wat by die internasionale aksie vanaf 1975 tot op datum betrokke was. 


\section{2. 'n Kort historiese oorsig}

Enige beskrywing van die geskiedenis moet volgens Overduin (1978:242-252) op die volgende gevare bedag wees:

- Alle weergawes van die geskiedenis is subjektief, maar mag nie in subjektivisme ontaard nie.

- Historici kan nie anders as om te veralgemeen nie, maar dit mag nie te ver gevoer word nie.

- Sowel 'n onkritiese veridialisering as 'n oorkritiese verwerping van wat die verlede opgelewer het, moet vermy word.

- Indien 'n mens self nou by die geskiedenis betrokke was, dreig die gevaar om jouself óf as held óf as martelaar voor te stel - in plaas daarvan om op God se getrouheid en genade die aandag te vestig.

Omdat hier "enkele persoonlike indrukke" (vgl. subtitel van artikel) gegee word, is veral laasgenoemde 'n wesenlike gevaar. Behalwe as martelaar (ek het gely) of as held (ek het 'n monument opgerig), kan 'n mens (al is dit onbewus) uit 'n strewe na erkenning jou persoonlike bydrae propageer deur jouself as "profeet" of "visionêr" voor te stel. Totdat 'n verkiesliker beoordeling deur 'n onafhanklike (nie-betrokke) skrywer beskikbaar is, moet egter voorlopig met hierdie meer persoonlike bydrae - ten spyte van sy gebreke, soos die veelvuldige verwysing na eie geskrifte - volstaan word.

Ter wille van oorsigtelikheid word die geskiedenis van IAPCHE in drie periodes ingedeel: sy kinder- en tienerjare, (1975 tot ongeveer 1987), die adolossensiejare (vanaf ongeveer 1987 tot 2000) en die volwasse jare (vanaf 2000-2005). Die gebruik van hierdie beelde beteken nie dat die skrywer 'n sikliese visie sou huldig waarvolgens die geskiedenis eenvoudig in opkoms, bloei, verval en ondergang ingedeel kan word nie.

\subsection{Voorgeskiedenis}

Voordat oor elkeen van hierdie periodes iets meer gesê word, moet die aandag daarop gevestig word dat mense van gereformeerdCalvinistiese oortuiging lank vóór 1975 al die behoefte gehad het om internasionaal nouer saam te werk. In dié verband kan die verskillende Internasionale Calvinistiese Konferensies genoem word wat reeds vanaf die dertigerjare van die vorige eeu gehou is (vir meer besonderhede vgl. De Vries, 1974). Na die Tweede Wêreldoorlog het die International Association for Reformed Faith and Action (IARFA) 'n aantal streeks- en internasionale konferensies 
gereël en gereeld die waardevolle International Reformed Bulletin uitgegee. Ongelukkig loop die organisasie in die tagtigerjare dood. In die vyftigerjare kom op kerklike gebied die Reformed Ecumenical Synod (wat later tot Reformed Ecumenical Council herdoop is) tot stand. (Vir meer besonderhede, vgl. Van der Walt, 1981:486 e.v.). Nie een van hierdie organisasies het hulle egter spesifiek die bevordering van Christelike hoër onderwys ten doel gestel nie. Die Internasionale Konferensie van Gereformeerde Instellings vir Christelike Hoër Onderwys van 1975 was die eerste van sy soort in die geskiedenis.

\subsection{Die kinder- en tienerjare (1975-1987)}

Voor die eerste konferensie was daar 'n goeie verhouding tussen die Vrije Universiteit (VU) en die PUK. In 'n deeglike studie (van twee dele) toon Schutte (2005) byvoorbeeld aan hoe 'n groot bydrae die VU gelewer het in die opleiding van Afrikaanse akademici in verskillende vakgebiede.

\subsubsection{Die VU uitgesluit in 1975 en ' $n$ internasionale konflik volg}

Nadat met die VU van Amsterdam, Nederland onderhandel is om so 'n konferensie aan te bied en dit nie gebeur het nie, neem die PU vir $\mathrm{CHO}$ die inisiatief.

Prof. H.J.J. Bingle (destydse rektor van die PU vir $\mathrm{CHO}$ ) het die VU ook na die konferensie uitgenooi. Nadat die VU egter laat weet het dat dr. Beyers Naudé (destyds direkteur van die Christelike Instituut en as gevolg van sy kritiek op apartheid nie gewild by die meeste blanke Suid-Afrikaners nie, maar wat 'n eredoktorsgraad van die VU ontvang het) ook deel van hulle afvaardiging na die konferensie sou wees, het Bingle egter sy uitnodiging aan die VU teruggetrek.

Die VU was dus nie op die heel eerste konferensie teenwoordig nie. Dit het egter nie beteken dat ander oorsese afgevaardigdes nie die VU se anti-apartheid standpunt gedeel het nie. Nadat van die SuidAfrikaanse sprekers tydens die konferensie dié ideologie probeer verdedig het, het 'n politieke stryd ontstaan wat vir langer as 'n dekade daarna die internasionale aksie sou vertroebel en nadelig beïnvloed. Dit het die voorheen goeie verhouding tussen die PUK en die VU versuur. Die hele internasionale gemeenskap het ook tussen een van die twee vegtende partye kant moes kies. Gesprekke is wel tussen die twee gehou, maar die lug is nie gesuiwer nie (vgl. Peterse, 2000:117-128 en Van Eeden, 2005:542-543). 


\subsubsection{Breukelen (1984) en daarna}

In 1981, voor die konferensie te Breukelen is besluit dat die PUK se lidmaatskap "besmet" is. Dit het prakties daarop neergekom dat die PUK uit die internasionale organisasie geskors is. Die Internasionale Klaringshuis moes gevolglik ook by die Instituut vir Reformatoriese Studie (IRS) gesluit word.

Die voortslepende konflik oor apartheid het sy hoogtepunt bereik op die Internasionale Konferensie wat in 1984 by die Kasteel Nijenrode in Breukelen, Nederland gehou is. Veral gedurende die eerste twee dae van die konferensie was die atmosfeer gelaai. Op die ou einde het veertien persone die konferensie verlaat. Hulle het tot die drastiese stap oorgegaan omdat hulle met die anti-apartheid Belydende Kring uit Suid-Afrika gesimpatiseer het. Dié Kring het die konferensie geboikot en geëis dat vyf ander (blanke) Suid-Afrikaners (onder wie die skrywer van hierdie artikel) die konferensie moes verlaat - terwyl nie een van die vyf blankes eers voorstanders van apartheid was nie. Ander het die konferensie verlaat omdat hulle nie saamgestem het met die geleentheid wat aan die Belydende Kring gegee is om die rede vir hulle protes te verduidelik nie.

Die spanning het nog voortgeduur tot met die Internasionale Konferensie wat in 1987 in Lusaka, Zambië gehou is. Eers by die streekkonferensie vir Suider-Afrika, gehou te Harare, Zimbabwe in 1991, kon weer gepraat word oor versoening en die hertoelating van die PUK tot die internasionale gemeenskap - dit het na meer as tien jaar, in 1993, eers gebeur.

\subsubsection{Voortdurende strukturele veranderings}

Hierdie jarelange konflik verklaar ook waarom die internasionale aksie so lank geneem het voordat dit as IAPCHE kon bekend staan. In die loop van die tyd het die volgende strukturele veranderings plaasgevind: Aan die begin (1975) was dit bloot 'n konferensie, die International Conference of Reformed Institutions for Christian Higher Education (ICRICHE). As gevolg van die genoemde spanning het die Tweede Internasionale Konferensie (1978 te Calvin College, Grand Rapids), besluit om nie soos beplan, 'n alliansie van instellings te vorm nie, maar eerder 'n los affiliasie. Die woord Reformed is ook laat vaar en die afkorting ICICHE (International Conference of Institutions for Christian Higher Education) is gebruik. As gevolg van die verdeeldheid tussen die deelnemende instellings is by die Derde Internasionale Konferensie in 1981 te Dordt College, Sioux Center, besluit om nie meer op instellings te fokus nie, maar om 'n onafhanklike raad van individue te vorm, wat min of meer die 
vertroue van die verskillende instellings geniet het. Die naam word toe die International Council for the Promotion of Christian Higher Education (ICPCHE). Die finale verandering het plaasgevind toe in 1987 by die Vyfde Internasionale Konferensie in Lusaka, Zambië besluit is om ' $n$ vereniging te vorm, naamlik die International Association for the Promotion of Christian Higher Education (IAPCHE). Daar is egter ook besluit dat alleen individuele lede stemreg sou hê, terwyl institusionele lede, wat die meeste finansiële steun voorsien het, nie kon stem nie. Dit was die enigste wyse waarop die jarelange stryd beëindig kon word.

\subsection{Die adolessensiejare van IAPCHE ${ }^{2}- \pm 1987$ tot 2000}

Die tweede periode kan in twee sub-fases verdeel word:

\section{- 'n Eerste fase}

Die eerste tien jaar ( \pm 1988-1996) kan beskou word as 'n tydperk van stilstand en daarom agteruitgang. Afgesien van ander faktore, kan dit ook toegeskryf word aan die lang siekte van die algemene sekretaris, dr. Paul Schrotenboer. Ten spyte van sy ernstige ongesteldheid kon hy nogtans daarin slaag om twee streekkonferensies te reël en 'n gereelde nuusbrief te publiseer.

\section{- 'n Tweede fase}

Die tweede subfase strek vanaf ongeveer 1997 tot 2000 en kan beskryf word as 'n tydperk van introspeksie en herlewing. Dr. John Hulst, vroeër president van Dordt College, Sioux Center, lowa, neem by Schrotenboer oor as algemene sekretaris en die internasionale kantoor van IAPCHE word saam met hom van Grand Rapids, Michigan na Dordt College verskuif. Gedurende hierdie drie jaar is nie nuwe raadslede verkies nie. Dié wie se termyne verval het is verleng om die nodige kontinuïteit te verseker. Daar moes ernstige besinning gedoen word oor feitlik alle aspekte, soos die doel, grondslag, programme en lidmaatskap van IAPCHE. Die resultate van hierdie selfondersoek is ter tafel gelê op die internasionale konferensie te Dordt College in Augustus 2000, waar op 'n hele nuwe plan van aksie besluit is.

2 Hoewel die organisasie IAPCHE in die loop van die geskiedenis verskillende name gehad het, word gerieflikheidshalwe deurentyd hierdie finale naam gebruik. 


\subsection{Volwassenheid (2000-2005)}

Die derde periode (2000-2005) kan as IAPCHE se volwasse jare aangedui word, omdat op die konferensie van Augustus 2000 'n goeie plan van aksie opgestel is. Verder kon die jong en dinamiese dr. Nick Latinga vanaf 2001 as algemene sekretaris en 'n bekwame sekretaresse, Anne Maatman, die leisels oorneem om die beplanning van 2000 daadwerklik uit te voer.

Inisiatiewe wat reeds onder die leiding van dr. Hulst begin is, is voortgesit en uitgebrei. Van die belangrikste is die volgende:

- In dié kort periode is, behalwe die genoemde internasionale konferensie van 2000, nie minder nie as ses streekkonferensies gereël.

- Die nuusbrief Contact het meer gereeld verskyn en ook 'n wyer terrein gedek.

- Jaarliks is 'n Directory met besonderhede van die IAPCHE-lede gepubliseer - later in elektroniese vorm.

- Lidmaatskap is ook uitgebrei en sluit tans die volgende vyf kategorieë in: individuele lede, studentelede, institusionele lede (verskillende Christelike kolleges en universiteite), konsulterende lede (verenigings wêreldwyd wat hulle ten doel stel om Christelike onderwys te bevorder) en geassosieerde lede, wat bestaan uit individue, stigtings, sakeondernemings, ensovoorts wat nie self aktief by akademiese werk betrokke is nie, maar weens hulle belangstelling in die bevordering van Christelike onderwys IAPCHE finansieel ondersteun. Dit is veral die institusionele lede en die geassosieerde lede wat sorg dat IAPCHE voldoende fondse het vir sy verskillende aktiwiteite.

- As gevolg van al hierdie aktiwiteite het instellings wat vroeër hulle lidmaatskap van IAPCHE gekanselleer het, weer aangesluit en talle nuwe lede het bygekom.

- Die Faith and Learning Network word geloods. Dit is 'n elektroniese bibliografie wat moeilik bekombare materiaal oor 'n Christelike benadering tot die wetenskap verskaf en deur die Institute for Christian Studies in Toronto met die steun van IAPCHE voorsien word.

- Die Christian Academic Studies Certificate (CASC) is beplan en tree in werking vanaf September 2005. Individue en instellings 
wêreldwyd sal daaraan deelneem (vir volledige besonderhede vgl. die bylaag tot Contact, 16(3), Mei 2005).

- Ten slotte het die Raad van IAPCHE ook besluit om groter selfstandigheid te gee aan die vyf verskillende streke waarin die organisasie georganiseer is, naamlik Afrika, Asië-Oseanië, Europa, Latyns-Amerika en Noord-Amerika.

Nadat die verlede kortliks in oënskou geneem is, kan die resultate daarvan in die hede geëvalueer word. Ook hierdie gedeelte is slegs enkele persoonlike indrukke en dit kan dus moontlik subjektief wees.

\section{3. 'n Kort evaluering van wat bereik is}

Eers word 'n aantal prestasies genoem waarna kortliks die negatiewe aspekte genoem word.

\subsection{Prestasies}

Christus se gelykenis van die mosterdsaadjie (Matt. 13:31,32; Mark. 4:30-32 en Luk. 13:18-21) is ook op IAPCHE van toepassing: die geloof in die "dag van klein dingetjies" (vgl. Sag. 4:10) is nie beskaam nie. Die mosterdsaadjie, wat dertig jaar gelede op Potchefstroom in geloof gesaai is, het vandag 'n groot "boom" geword met "takke" oor die hele wêreld waarin baie "voëls" (Christenonderwysers en akademici) tuis kan voel. Die volgende is daarvan 'n bewys.

\section{- Handhawing van die internasionale eenheid}

Die vroeëre internasionale Calvinistiese aksies (vgl. De Vries, 1974) het veral as gevolg van konfessioneel-dogmatiese (dit wil sê kerklike) verskille en geskille doodgeloop. Soos aangetoon, het politieke verskille IAPCHE vir vyftien jaar (1975-1990) byna lamgelê. Op die keper beskou, het dit nie oor suiwer politieke verskille gegaan nie, maar oor die rol wat Christelike wetenskapsbeoefening in die samelewing in die algemeen en die apartheidspolitiek in die besonder behoort te speel. Verder was dit ook 'n stryd tussen 'n groep meer behoudende gereformeerdes (die PUK-groep) en die meer liberales (die VU-groep).

Menslik gesproke kon dit nie slaag nie. Dat eenheid wel behou is, is 'n wonder - genade van bo. Eenheid in die geloof het uiteindelik geseëvier. Baie persone wat deur die moeilike jare die leiding geneem het was so oortuig van die belangrikheid van IAPCHE dat hulle bereid was om deur alles heen vol te hou. 


\section{- Die waarde vir individue, instellings en organisasies}

Sowel die ooreenkomste (geesgenootskap) as die verskille in die internasionale gemeenskap van IAPCHE die afgelope dertig jaar was verrykend en het die lewens van individuele wetenskaplikes en instellings vir Christelike hoër onderwys gevorm.

Om hierdie invloed te meet is nie eenvoudig nie. Die skrywer kan alleen homself en die instelling waaraan hy verbonde was as voorbeelde gebruik. Sy eie denke is deur die ontmoeting met medeChristenwetenskaplikes dwars oor die wêreld verruim en verryk.

Ten spyte van die spanning wat dit vir die PUK veroorsaak het, het die internasionale druk teen dié inrigting se (stilswyende) goedkeuring van die apartheidsideologie tog ook 'n positiewe invloed gehad op individuele personeellede en uiteindelik die instelling self. Die PUK kon van 'n internasionaal geïsoleerde instelling ontwikkel tot wat dit vandag is. Vanselfsprekend word hiermee nie die bydrae van die interne druk in Suid-Afrika self negeer nie.

\section{- Die waarde van IAPCHE-konferensies}

Christenwetenskaplikes wat vroeër in isolasie moes werk, kon deur die IAPCHE-konferensies mekaar van aangesig tot aangesig ontmoet. Die blote luister hoe medekollegas in ander wêrelddele die uitdaging van Christelike hoër onderwys aanpak, het gelei tot wedersydse inligting en bemoediging. Selfs waar daar verskille was, moes hulle na mekaar luister en probeer verstaan. Nie net die gesigspunte van ander is verander nie, maar ook 'n mens se eie. Spreuke 27:17 sê tereg: "Yster slyp yster, só slyp die een mens die persoon [ook die denkbeelde] van die ander" (OAV). Omdat al die lesings van dié konferensies gepubliseer is, kon ook diegene wat nie die konferensies kon bywoon nie, daarby baat vind.

IAPCHE het die afgelope dertig jaar twee soorte konferensies aangebied, naamlik streeks- en internasionale byeenkomste. Die bedoeling van streeksbyeenkomste was om aandag te gee aan die unieke streekskontekste waarbinne Christelike wetenskapsbeoefening en onderrig moet plaasvind. Internasionale konferensies het meer op die globale uitdagings op die gebied van Christelike hoër onderwys gefokus. Dié twee kan egter nie waterdig van mekaar geskei word nie: op verskeie internasionale konferensies (bv. 1987) het streeksprobleme ook duidelik gefigureer, en die streekkonferensies was streng gesproke internasionaal van aard, omdat mense uit verskeie lande saam vergader het. 
In die Addendum is ' $n$ lys van die handelinge van al die konferensies (in chronologiese volgorde soos hulle plaasgevind het en nie volgens die publikasiedatums van die acta nie). Slegs één streekkonferensie, naamlik dié een oor "A Christian worldview and Christian scholarship", wat in 1997 in Nairobi, Kenia gehou is, se proceedings is nie gepubliseer nie.

Die volgende internasionale konferensie sal DV vanaf 14-19 November 2006 in Granada, Nicaragua gehou word.

\section{- Publikasies}

IAPCHE het drie soorte publikasies die lig laat sien: Die handelinge van veertien verskillende konferensies; 'n Nuusbrief (eers die Circular wat namens IAPCHE uitgegee is deur die IRS te Potchefstroom (1975-1981), toe die Bulletin (1981-1987), en daarna Contact); 'n Directory wat besonderhede van IAPCHE-lede bevat en gereeld (tans elektronies) opgedateer word. Met elkeen van hierdie publikasies word belangrike inligting oor Christelike onderwys internasionaal bekendgestel.

\section{- Behoud van 'n basiese visie}

Vir integrale Christelike wetenskapsbeoefening is vyf basiese boustene nodig: die religieuse, lewensbeskoulike, filosofiese, vakwetenskaplike en professionele toepassing. Dit kan met vyf sirkels voorgestel word wat mekaar oorvleuel, omdat die vyf elemente nie waterdig van mekaar geskei kan word nie (vgl. Van der Walt, 2005a:151).

Vir sommige Christenwetenskaplikes beteken Christelike wetenskapsbeoefening slegs 'n integrasie van die religieuse en vakwetenskaplike terrein. Dikwels impliseer dit 'n integrasie tussen die teologie (Christelik) en 'n vakwetenskap (byvoorbeeld die ekonomie of psigologie). Teenoor die standpunt van óf geloof óf wetenskap (van diegene wat nie in 'n Christelike benadering tot die wetenskap glo nie), is hierdie die standpunt van geloof én wetenskap. Omdat enige wetenskaplike aktiwiteit egter deur voorwetenskaplike, religieuse, lewensbeskoulike en filosofiese vertrekpunte bepaal word, is die korrekte standpunt myns insiens gelowige wetenskap - wat vir sowel die Christen as die nie-Christen geld (vgl. Van der Walt, 1992 en Van der Walt, 2004a:17-18).

Botha (2005) toon die groot verskil by Noord-Amerikaanse Christene se idee van Christelike wetenskap aan tussen die Evangelicals aan 
die een kant en die Reformatoriese denkers aan die ander kant. By eersgenoemde heers die integrasiemodel.

Hierdie integrasiepogings sit nog sterk vas aan 'n dualistiese instelling waarin geloof primêr met Teologie en die Bybel en die 'geestelike' lewe verband hou en wetenskap dikwels vrywel neutraal beskou word. 'n Groot deel van die bydrae van die Reformatoriese medewerkers ... bestaan daarin dat hulle die grondliggende tweedeling van die lewe wat aan dié integrationtaal ten grondslag lê, bevraagteken en in praktyk en voorbeeld probeer aantoon hoe die 'integriteit' van die lewe nie sodanige tweedeling duld nie (Botha, 2005:13).

Dat die integrasiemodel van geloof én wetenskap nie tot werklike integrale Christelike wetenskap kan lei nie, word onder meer breedvoerig beredeneer deur Bouma-Prediger (1990), Sinnema (2001), Van Belle (2005) en Van der Walt (2006).

In die visie van IAPCHE is die bogenoemde elemente wel verreken, naamlik die Christelik-religieuse vertrekpunt, die lewensbeskoulike verbreding en die filosofiese begronding en verdieping, wat nodig is vir 'n uiteindelike integraal-Christelike (vak)wetenskap.

Christelik mag nie in die eng kerklike betekenis daarvan of in 'n teologiese sin alleen verstaan word nie. Daarmee kan die sekularisasie van die wetenskap nie voorkom of teëgewerk word nie. 'n Poging om die sekulêre wetenskappe te "verteologiseer" loop uiteindelik uit op die versekularisering van die teologie self.

Afgesien daarvan dat kerklike en teologiese dominasie nie tot ware Christelike wetenskap kan lei nie, is IAPCHE ook nie positief oor die gedagte dat wetenskap en onderwys in die algemeen deur 'n sekulêre staat bepaal sal word nie. Sy visie is dié van selfstandige Christelike onderwysinstellings wat vry is van sowel kerklike (in casu dogmatiese) as politieke oorheersing.

Hoewel mense soos Vander Stelt (1990 en 1996) en Van der Walt (2006) bogenoemde visie voorstaan, impliseer dit nie 'n amptelike standpunt by IAPCHE nie. IAPCHE se amptlike visie gee slegs breë perspektiewe wat verskillend geïnterpreteer kan word. In die praktyk is mense en instellings met verskillende standpunte oor Christelike wetenskapsbeoefening lede van hierdie organisasie.

\section{- Waardevolle stimuli vir Christelike wetenskapsbeoefening}

Twee ander prestasies is (vgl. 2.4) die Faith and Learning Network, asook die Christian Academic Studies Certificate. Hierdie twee 
projekte kan waardevol wees veral vir mense wat nog nie met dié unieke visie van IAPCHE kennis gemaak het nie, of nie oor die nodige materiaal beskik nie, of nie die voorreg het om aan 'n Christelike instelling te studeer nie.

\section{- Die positiewe uit die negatiewe gebore}

Dat God in die geskiedenis op merkwaardige, onvoorspelbare maniere werk moet spesiaal vermeld word. Aan die begin van die tagtigerjare was die PUK so moeg van die stryd op internasionale toneel dat besluit is om vanuit die IRS liewer op Afrika toe te spits. Gedurende die apartheidsera het Suid-Afrika die res van Afrika feitlik vergeet. Dit was 'n terra incognita - eers vanaf die Middellandse See het die "beskaafde" wêreld weer begin.

Die ironie skuil daarin dat God juis deur die spanning met die Westerse wêreld die Universiteit gedwing het om van sy naaste bure (die Afrikalande ten noorde van die RSA) kennis te neem. Vanaf 1983 tot en met die sluiting van die IRS in 1999 is waardevolle kontakte met Afrikalande in Sentraal-, Oos- en Wes-Afrika, tot in Nigerië, gemaak. Vooraanstaande leiers is geïdentifiseer wat belangrike bydraes, ook by wyse van geskrifte, tot die Christendom in Afrika gemaak het. (In Van der Walt [1989] word van die ideale wat destyds in dié verband gekoester is, uitgespel.) Baie van die leiers het ook, omdat hulle al onafhanklikheid agter die rug gehad het, op IRS-konferensies Suid-Afrikaners voorberei vir 'n nuwe demokratiese bedeling aan die suidpunt van Afrika. Die ideaal wat tien jaar gelede (vgl. Van der Walt, 1994:385-396) alreeds vir die PUK gestel is, naamlik dat dit eendag 'n universiteit van en vir Afrika sal word, is vandag besig om te gebeur.

\subsection{Negatiewe fasette}

Terugskouend op die afgelope drie dekades sou die volgende kritiese opmerkings gemaak kon word (sommige hiervan geld gelukkig nie meer nie):

- Gedurende die helfte van die bestaan van IAPCHE (1975 tot \pm 1990) het die institusionele lede mekaar gekritiseer in plaas van ondersteun.

- In baie gevalle was IAPCHE (lede, bestuur, konferensies) beter in dit wat hulle gesê as gedoen het. Reeds in 1976 (Bingle e.a., (1976:417-418) word twaalf sleuteltake genoem wat aangepak moes word en, alhoewel sommige take wel uitgevoer is, kon seker veel méér gedoen gewees het. 
- Baie van die IAPCHE-konferensies het telkens weer dieselfde algemene vrae oor Christelike wetenskapsbeoefening en onderwys behandel. Voldoende aandag is nie gegee aan die manier(e) waarop vakwetenskaplikes hulle spesifieke dissiplines as Christene moet transformeer nie. Tot 'n mate was dié verloop begryplik, omdat 'n steeds nuwe "gehoor" in die loop van dertig jaar van IAPCHE se basiese visie oortuig moes word.

- Aanvanklik was die benadering van IAPCHE sterk Eurosentries georiënteerd. Later is egter met die unieke kontekste van Afrika, die Ooste, Latyns-Amerika en die vroeëre Oosbloklande rekening gehou - veral by die streekkonferensies.

- Omdat die instellings vir Christelike onderwys van die begin af 'n sleutelrol in IAPCHE gespeel het, is veral gekonsentreer op individuele wetenskaplikes aan hierdie instellings. Ongelukkig het dit geskied saam met die verwaarlosing van die veel groter aantal Christene wat onder moeilike omstandighede aan sekulêre instellings moes werk.

- Hoewel IAPCHE alleen as 'n netwerk wou dien om skakeling te fasiliteer, was die kontakte wat tussen individuele wetenskaplikes en instellings gelê is, veral by konferensies, té insidenteel en ad hoc in plaas van volgehou en gestruktureerd. Dié blaam kan natuurlik ook op die betrokke individue en instellings gelê word wat nie die geleenthede wat deur IAPCHE geskep is, ten volle benut het nie.

- Veral aan die begin is sterk klem op die sentrum gelê om die internasionale eenheid te behou. Dit het 'n soort organisasie vanbo-na-onder tot resultaat gehad. Die besluit om sedert 2004 aan die vyf streke meer selfstandigheid te gee was egter 'n doelbewuste poging om sover moontlik te desentraliseer en te kontekstualiseer.

- Samehangend met die Eurosentriese tendens het die neiging ook bestaan om soms eensydig gepreokkupeer te wees met die stryd teen en die ontmaskering van valse en gevaarlike ideologieë by mense en gemeenskappe. Op sigself is dit 'n lofwaardige, noodsaaklike taak. Die vraag kan egter gestel word of genoeg gedoen is om ook die gevolge van die ideologieë wetenskaplik te verlig. Baie van die lyding van miljoene mense vandag is nie noodwendig die gevolg van een of ander ideologiese onderdrukking nie - nalatigheid en onkunde, selfsug, hebsug, magsug of natuurrampe kan ook daartoe bydra. Wetenskaplike werk is 
wel intellektueel van aard, maar mag nie ontaard in 'n intellektualistiese ivoortoringbedryf sonder enige bewoënheid en relevansie vir 'n sugtende wêreld nie.

\section{Die toekoms}

Hierdie oorsig sou goedskiks afgeskiet kon word met die wens dat IAPCHE se sterk punte nog sterker ontwikkel, terwyl sy swak punte sal verminder. Om óf profeet te probeer speel óf voorskriftelik te wees oor wat behoort te gebeur, is onvanpas. Hoewel ook dít 'n vanselfsprekendheid is, word die aandag daarop gevestig dat die wêreld aan die begin van die 21ste eeu nie meer dieselfde is as dertig jaar gelede (1975) nie. Polities, sosiaal en ekonomies het internasionaal, in Suid-Afrika en aan die Noordwes-Universiteit feitlik 'n nuwe wêreld ontstaan. Ook die geestesklimaat het verander.

\subsection{Veranderinge op internasionale gebied}

Enkele voor die hand liggende kenmerke van die nuwe tyd is die volgende:

- Die ystergordyn tussen die Weste en die Oosbloklande is afgebreek.

- Die ontwikkeling van veral die elektroniese media het vinniger en goedkoper kommunikasie moontlik gemaak en dit het 'n invloed ook op die onderwys.

- Die neo-kapitalisme het die heersende ideologie geword, en bring genadelose kompetisie en verkommersialisering van feitlik alles mee - ook hoër onderwys.

- Die oorheersende geestesklimaat vandag is dié van postmodernisme, wat 'n verskerpte vorm van irrasionalistiese relativisme behels. Die grootste teenstander van 'n Christelike benadering tot die wetenskap was in 1975 nog die neutraliteitsidee - vandag is dit 'n nuwe soort sekularisme. Op die oog af is ook die Christelike standpunt in die akademie welkom, maar dieper beskou is dit nie die geval nie - ten minste nie wanneer dit nie met die relativistiese standpunt akkoord gaan dat alle visies ewe waar is nie.

In die lig hiervan het Christelike organisasies en instellings vandag nog belangriker geword as dertig jaar gelede (vgl. Buijs e.a., 2003; Klapwijk, 1995 en Van der Walt, 2003). 


\subsection{Veranderinge op nasionale en plaaslike terrein}

Die volgende kan genoem word:

- Suid-Afrika het (sedert 1994) van 'n apartheid na 'n postapartheid bedeling ontwikkel en is uit die greep van internasionale isolasie bevry.

- Die nuwe godsdienstig-neutrale konstitusie het ook ernstige probleme vir veral oortuigde Christene, Christelike instellings en organisasies meegebring. Geloofsvryheid is belangrik. Christene behoort nie van die staat te verwag om hulle eie geloof te bevoordeel en te bevorder nie. In die praktyk word vandag egter, subtiel, die sekulêre geloof (wat in die Suid-Afrikaanse Grondwet verskans is) op alle gelowe - die Christelike inkluis - afgedwing. (Meer hieroor in Van der Walt, 2004b; 2004c en 2005b). Dit geld ook vir die onderwys op alle vlakke.

- As gevolg van die politieke verandering wat besig was om in die land plaas te vind, kon die PUK ook weer lidmaatskap van IAPCHE bekom. Verder is die verbroke bande met die VU (vgl. Peterse, 2000:129-132) en ander buitelandse inrigtings herstel (vgl. Van Eeden, 2005:541-543) en nuwe oorsese bande is aangeknoop.

- Die nuwe bedeling in Suid-Afrika het ook daartoe bygedra dat die PUK se naam in 2004 verander is na Noordwes-Universiteit (NWU) en dat dit nie net sy van ("vir Christelike Hoër Onderwys") verloor het nie, maar dalk ook sy Christelike identiteit. Hoewel ooreengekom is dat die Potchefstroomkampus 'n eie identiteit mag behou, sal net die tyd leer wat in die praktyk gebeur. Die NWU sal egter wel 'n waardegedrewe instelling wees (vgl. Van Eeden, 2005:89,00). In die visiekanselier, dr. T. Eloff, se rede by die herfsgradeplegtigheid (13 Mei 2004) word enkele van die nuwe waardes van die NWU genoem. Daaruit is dit duidelik dat die nuwe gemeenskaplike waardes wat dié Universiteit se koers in die toekoms moet bepaal aan die sekulêre Suid-Afrikaanse Grondwet ontleen is. Is dit voldoende om 'n eie Christelike identiteit vir die Potchefstroomkampus te waarborg?

Hierdie nuwe internasionale en nasionale konteks roep om nuwe antwoorde op die gebied van Christelike wetenskapsbeoefening en onderwys. Die "contemporary challenge" (vgl. die subtitel van die acta van die eerste konferensie van 1975) sal herskryf moet word. 


\section{3 'n Wens}

Dat dié uitdaging met entoesiasme deur Christelike wetenskaplikes wêreldwyd aanvaar word, blyk uit die skrywer se ervaring by die IAPCHE-konferensies in verskillende wêrelddele gedurende 2005.

Dit het byvoorbeeld tydens die IAPCHE-konferensie vir die Ooste in Januarie 2005 in Indië duidelik geblyk: ten spyte van die feit dat die Christendom in dié lande ver in die minderheid is $( \pm 2 \%$ van die totale bevolking) het hulle ook sekulêre konstitusies. Hoewel Christene in ander Afrikalande onder veel groter armoede gebuk gaan as Suid-Afrikaners, was die IAPCHE-konferensie in Nairobi, Kenia (Maart-April 2005) nie minder entoesiasties oor Christelike onderwys nie. Dieselfde was die geval by die IAPCHE-konferensie in Rusland (Augustus 2005) - ten spyte van die feit dat die Christendom nou eers weer begin herleef na jarelange wrede ateïsties-kommunistiese onderdrukking.

My hartewens is dat die entoesiasme vir 'n scientia reformata op Potchefstroom in die toekoms net so groot sal wees as elders in die wêreld in gebiede waar 'n mens dit nie sou verwag nie.

\section{5. 'n Versoek}

Hierdie bydrae vorm deel van 'n spesiale uitgawe van Koers, bulletin vir Christelike Wetenskap, wat uit waardering aan die nuwe rektor van die Potchefstroomkampus, prof. Annette Combrink, opgedra word. Voorheen was sy vir baie jare hoofredakteur van hierdie blad en ook vir 'n korter periode Dekaan van die Fakulteit Lettere en Wysbegeerte. In die verlede het sy ook die saak waarvoor IAPCHE staan op die hart gedra en ondersteun.

Soos van enige nuwe rektor word van haar - veral as eerste vroulike rektor in die geskiedenis van hierdie kampus - veel verwag. Mag die saak wat in hierdie artikel aangeroer is, ook in die toekoms 'n belangrike plek op haar prioriteitslys vind.

\section{Geraadpleegde bronne}

BINGLE, H.J.J. et al. 1976. Christian higher education: the contemporary challenge. Potchefstroom: Institute for the Advancement of Calvinism.

BOTHA, M.E. 2005. Hoe staan dit met Christelike onderwys in Noord-Amerika (VSA en Kanada)? Woord en Daad, 44(390):12-16, Somer.

BOUMA-PREDIGER, S. 1990. The task of integration: a modest proposal. Journal of Psychology and Theology, 18(1):21-31.

BUIJS, G. e.a. 2003. Wat je zegt, ben jezelf: identiteit en Christelijke organisaties. Zoetermeer: Boekencentrum. 
DE VRIES, W.G. 1974, Calvinisten op de tweesprong: de Internationale Federatie van Calvinsten en haar invloed op die onderlinge verhoudingen in de gereformeerde kerken in Nederland in die dertiger jaren van de twintigste eeuw. Groningen: De Vuurbaak.

HULST, J.B. 2005. A doorkeeper at God's household: the memoirs of John B. Hulst. Sioux Center: Dordt College Press.

KLAPWIJK, J. 1995. Christelijke organisaties in verlegenheid. (In Klapwijk, J. Transformationele filosofie: cultuurpolitieke ideën en de kracht van een inspiratie. Kampen: Kok Agora. p. 91-123.)

KLEP, P., HOETINK, C. \& EMONS, T., reds. 2000. Persoonlijk verleden: over geschiedenis, individu en identiteit. Amsterdam: Aksant.

OVERDUIN, J. 1978. Faith and victory in Dachau. St. Catherines: Paideia.

PETERSE, R. 2000. Opkomst, ondergang en wederopstanding van een internationale universitaire samewerkingsrelatie: een historische studie over de verhouding tussen de VU en PU vir CHO. Amsterdam: Vrije Universiteit. (Ongepubliseerde doktoraalskripsie.)

SCHUTTE, G. 2005. De Vrije Universiteit en Zuid-Afrika, 1880-2005. Amsterdam: Vrije Universiteit.

SINNEMA, D. 2001. Beyond integration to holistic Christian scholarship. (In Kok, J.,ed. Marginal resistance: essays in honour of John C. Vander Stelt. Sioux Center: Dordt College. p. 187-208.)

VAN BELLE, H. 2005. Structure and direction: recounting the presence of God in the therapeutic relation. Lesing gelewer op 11/05/2005 by die Potchefstroomkampus van die Noordwes-Universiteit. Potchefstroom: Noordwes-Universiteit.

VAN DER WALT, B.J. 1981. Panorama Reformationis anno Domini MCMLXXX: a survey of worldwide Reformed faith and action. (In Van der Walt, B.J. Anatomy of reformation. Potchefstroom: Institute for the Advancement of Calvinism. p. 486-506.)

VAN DER WALT, B.J. 1989. Potchefstroom, Afrika roep jou! Die Reformatoriese lewensvisie en die dringende missie van die $\mathrm{PU}$ vir $\mathrm{CHO}$ op die Afrikaanse kontinent. (In Van der Walt, B.J. Visie en missie: IRS 25 jaar. Potchefstroom: IRS. p. 13-70.)

VAN DER WALT, B.J. 1992. Christelike wetenskapsbeoefening onderweg. Potchefstroom: Instituut vir Reformatoriese Studie. (Studiestuk nr. 297.)

VAN DER WALT, B.J. 1994. Flitsgedagtes oor die identiteit van die PU vir CHO. (In Verkenning en oorgang: gedagtes by die 125-jarige bestaan van die PU vir CHO. Supplement 1 tot Koers, 1998. p. 361-400.)

VAN DER WALT, B.J. 2002. Our past heritage, present opportunity, and future challenges: reflections on the 25th anniversary of the IAPCHE. Christian Higher Education, $1(1$ \& 2):123-137.

VAN DER WALT, B.J. 2003. Identiteit en relevansie: die dringende noodsaaklikheid van Christelike organisasies en instellings in 'n toenemende sekulêre Suid-Afrika. Tydskrif vir Christelike Wetenskap, 39 (3e \& 4e kwartaal):131-148.

VAN DER WALT, B.J. 2004a. Die verhouding tussen geloof en wetenskap. Die Kerkblad, 107(3169):17-19, November.

VAN DER WALT, B.J. 2004b. Sekularisme, die gees van ons tyd (1): 'n bedreiging. Tydskrif vir Christelike Wetenskap, 40(1e \& 2e kwartaal):8597. 
VAN DER WALT, B.J. 2004c. Sekularisme, die gees van ons tyd (2): 'n tipering. Tydskrif vir Christelike Wetenskap, 40(3e \& 4e kwartaal):102-123.

VAN DER WALT, B.J. 2005a. Taking captive every thought to make it obedient to Christ. (In Van der Walt, B.J. Transformed by the renewing of your mind. Potchefstroom: The Institute for Contemporary Christianity in Africa. p. 130-166.)

VAN DER WALT, B.J. 2005b. Sekularisme, die gees van ons tyd (3): 'n antwoord. Tydskrif vir Christelike Wetenskap, 41(1e \& 2e kwartaal):43-74.

VAN DER WALT, B.J. 2006. Integrasie of transformasie? "Geloof en wetenskap" of "gelowige wetenskap" as vertrekpunte vir integrale wetenskapsbeoefening. Koers, 70(3):373-399.

VAN EEDEN, E.S., red. 2005. "In U lig": die PU vir $\mathrm{CHO}$ van selfstandigwording tot samesmelting. Potchefstroom: Noordwes-Universiteit.

VANDER STELT, J.C. 1990. IAPCHE: past and future challenges. (In Hulst, J.B. et al. Rainbow in a fallen world: unity and diversity in Christian higher education today. Sioux Center: Dordt College. p. 10-22.)

VANDER STELT, J.C. 1996. History and vision of IAPCHE. (In Schrotenboer, P.G., ed. Christian higher education in Eastern Europe. Sioux Center: Dordt College. p. 13-30.)

\section{ADDENDUM}

Acta (in chronologiese volgorde van konferensiesdatums) van internasionale en streekskonferensies vir Christelike hoër onderwys (1975-2005)

BINGLE, H.J.J. et al. 1976. Christian higher education: the contemporary challenge. (Proceedings of the First International Conference of Reformed Institutions for Christian Scholarship. Potchefstroom, 9-13 September 1975). Potchefstroom: Institute for the Advancement of Calvinism.

WOLTERSTORFF, N. et al. 1978. Responsibility of Christian institutions of higher education to justice in the international economic order. (Proceedings of the Second International Conference of Reformed Institutions for Christian Higher Education. Calvin College, Grand Rapids, 13-19 August 1978). Grand Rapids: Calvin College.

VANDER STELT, J.C., ed. 1982. The challenge of Marxist and neo-Marxist ideologies for Christian scholarship. (Proceedings of the Third International Conference held in 1981 at Dordt College). Sioux Center: Dordt College.

VANDER STELT, J.C., VERHEUL, H. et al. 1987. Challenge and critique of Christian higher education. (Proceedings of the International Conference of IAPCHE held in 1984 in the Netherlands). Kampen: Kok.

HULST, J.B. et al. 1990. Rainbow in a fallen world: diversity and unity of Christian higher education today. (Proceedings of the 1987-conference of the International Council for the Promotion of Christian Higher Education, Lusaka, Zambia). Sioux Center: Dordt College.

ROOY, S. et al. 1990. Educado como Christianos en el siglo xxi. (Memoria del Primer Encuentro Latinamericano de la Association International para la Promotion de la Education Christiana Superior, Costa Rica, 18-12 de enero de 1999). AIPECS: Costa Rica. 
VAN DER WALT, B.J. et al. 1992. Christian education in the African context. (Proceedings of the African regional conference of the International Association for the Promotion of Christian Higher Education, 4-9 March 1991, Harare, Zimbabwe). Grand Rapids: IAPCHE.

VAN DER WALT, B.J. et al. 1993. Integral Christian scholarship: exploratory reflections on the African situation. (Proceedings of the conference in May 1992 at Potchefstroom University, South Africa). Potchefstroom: Institute for Reformational Studies.

SCHROTENBOER, P.G., ed. 1996. Christians and higher education in Eastern Europe. (The proceedings of the 1993-Debrecen regional conference of the International Association for the Promotion of Christian Higher Education). Sioux Center: Dordt College.

PECHERSKAYA, Natalia, ed. 1999. Higher education in the xxi century Russian culture: a Christian perspective. (Proceedings of the IAPCHE regional conference in St. Petersburg, May 24-26, 1999). IAPCHE \& SRPH: St. Pietersburg.

LUMSDEN, D.B., ed. 2002. Challenges for Christian Higher Education in the $21^{\text {st }}$ century. Christian Higher Education: a journal of applied research and practice, $1(2 \& 3): 1-324$. (Proceeding of the International IAPCHE Conference at Dordt College, Sioux Center, lowa, USA from August 12-16, 2000).

HULST, J.B. \& BALLA, P., eds. 2003. The Word of God for the academy in contemporary culture. (Proceedings of the regional conference for Europe of IAPCHE hosted by Károli Gáspár Reformed University, Budapest, Hungary, July 3-6, 2002). Sioux Center: IAPCHE \& Budapest: Károli Gáspár Reformed University (Faculty of Theology).

HULST, J.B., ed. 2004. Christian worldview and scholarship. (Proceedings of the regional conference of IAPCHE for Western Africa, January 10-16, 1999, Mkar, Nigeria). Melbourne: Amani Educational Services.

MONDRAGÓN, C., ed. 2004. Los retos del conocimiento: la education cristiana en un mundo globalizado. Beunos Aires: Ediciones Kiaros.

Die volgende proceedings word binnekort gepubliseer:

Acta van die IAPCHE streekkonferensie vir Asië/Oseanië vanaf 14-17 Januarie 2005, gehou in Chennai (Madras), Indië.

Acta van die IAPCHE streekkonferensie vir Afrika vanaf 31/03 - 03/04/2005, gehou in Nairobi, Kenia.

Acta van die IAPCHE streekkonferensie vir Europa vanaf 20-23 Augustus 2005, gehou in Moskou, Rusland.

(Navrae oor al hierdie publikasies kan gerig word aan die hoofkantoor van IAPCHE, Dordt College, 498 Fourth Avenue N.E., Sioux Center, lowa 51250-1697, VSA. E-pos: iapche@dordt.edu).

\section{Kernbegrippe:}

Christelike hoër onderwys

Christelike wetenskap; beoefening van

International Association for the Promotion of Christian Higher

Education (IAPCHE)

Noordwes-Universiteit; Potchefstroomkampus 


\section{Key concepts:}

Christian higher education

Christian scholarship

International Association for the Promotion of Christian Higher

Education (IAPCHE)

North-West University; Potchefstroom campus 